\title{
A check list of the spiders of the Kruger National Park, South Africa (Arachnida: Araneae)
}

\section{Anna S. DippenaAR-Schoeman and A. Leroy}

Dippenaar-Schoeman, Anna S. and A. Leroy. 2003. A check list of the spiders of the Kruger National Park, South Africa (Arachnida: Araneae).Koedoe 46(1): 91-100. Pretoria. ISSN 0075-6458.

As part of the South African National Survey of Arachnida (SANSA), projects are underway to determine the biodiversity of arachnids present in protected areas in South Africa. Spiders have been collected over a period of 16 years from the Kruger National Park, South Africa. A check list is provided consisting of 152 species, 116 genera and 40 families. This represents about $7.6 \%$ of the total known South African spider fauna. Of the 152 species, 103 are new records for the park. The ground dwelling spiders comprise 58 species from 25 families. Of these, $21 \%$ are web dwellers and $62 \%$ free living, while $17 \%$ live in burrows. From the plant layer, 94 species have been collected of which $53 \%$ were web builders and $47 \%$ free living wandering spiders.

Key words: Araneae, biodiversity, check list, Kruger National Park, South Africa, spiders.

Anna S. Dippenaar-Schoeman, ARC-Plant Protection Research Institute, Private Bag X134, Pretoria 0001, Republic of South Africa; Astri Leroy, P.O. Box 2810, Wilropark, 1731, Republic of South Africa.

\section{Introduction}

Conservation biologists are starting to recognise the importance of the invertebrate component in the functioning of healthy ecosystems. Therefore, any approach to conservation needs to take into account the composition of these invertebrate fauna. Inventories, with resulting check lists, provide valuable baseline information on species present and are the first step toward a better understanding of the fauna of the area.

In 1997, the South African National Survey of Arachnida (SANSA) was initiated (Dippenaar-Schoeman \& Craemer 2000) with its main aim to make an inventory of the arachnid diversity of South Africa. One of the projects of SANSA is to compile an inventory of spiders presently conserved in parks and reserves in South Africa.

Although spiders constitute an abundant and highly diverse group of invertebrate animals, little is still known about their diversity even in conserved areas. From South Africa check lists exist for the spider fauna of the Moun- tain Zebra National (Dippenaar-Schoeman 1988), Roodeplaat Dam Nature Reserve (Dippenaar-Schoeman et al. 1989), Karoo National Park (Dippenaar-Schoeman et al. 1999), Makelali Nature Reserve in the Limpopo Province (Whitmore et al. 2001) and the Western Soutpansberg (Foord 2002).

The aim of this study was to compile the first check list of the spider species of the Kruger National Park (KNP) and to determine the percentage of species protected. This was not an intensive survey but reflects on collecting done in the park over a period of 16 years. Although this survey may not reflect the true diversity and species richness of the area, it does give an indication of species present.

\section{Material and methods}

\section{Study area}

The Kruger National Park (KNP) is situated in the Lowveld region of the Mpumalanga and Limpopo Provinces of South Africa. The park is $350 \mathrm{~km}$ long 
from north to south with a surface area of 1948528 ha. The climate is subtropical, with the annual rainfall varying between $700 \mathrm{~mm}$ in the south and $400 \mathrm{~mm}$ in the north. It falls within the Savanna Biome and the vegetation includes mixed bushwillow woodlands, mountain bushveld, thorn thicket, thorn veld, sourveld, scrubveld, sandveld and riverine forest.

\section{Collecting methods}

Sporadic collecting was mainly undertaken from 1985 to 2001. Spiders were sampled by hand (ground and plant search, turning rocks and sifting of leaf litter) or using a sweepnet or beating tray for grass and low shrubs. The new records were identified by the first author and are housed in the National Collection of Arachnida (NCA) at the ARC-Plant Protection Research Institute in Pretoria. The lack of taxonomic research in southern Africa within certain families made the identification of some genera to species level impossible. In some families, only immature specimens were collected, hampering identification to species level. This means that, in both instances, only generic names are included in the check list. The species list includes published

Table 1

Guild classification of spiders collected in the Kruger National Park.

Guilds Abbreviation Guild explanation

WANDERING SPIDERS (W)

Ground wandering spiders (GW)

$\begin{array}{lll}\text { Free living } & \text { FGW } & \text { free-living spiders running on the soil surface when active } \\ \text { Burrow living } & \text { BGW } & \text { living in burrows }\end{array}$

Plant wandering spiders (PW)

Free living FPW free-living spiders running on the plant surface when active

WEB-BUILDING SPIDERS (WB)

Orb-web OWB

orb-webs consisting of a frame with mooring and bridge lines that anchors the web and radial signal threads arranged like the ribs of a umbrella converging onto the centre of the web with circular spiral threads

Funnel-web $\quad$ FWB sheet-webs made over soil surface with a funnel-shaped retreat

Gumfoot-web GWB three-dimensional webs consisting of a central area with or without a retreat. The upper part comprises mooring, signal and catch threads and a lower part with mooring and catch threads. The lower catch threads studded with sticky droplets are attached to the substrate

Retreat-web RWB silk threads used to catch prey radiating from retreat

Sheet-web SHWB sheet-webs which, usually consists of an upper sheet with mooring, signal and catch threads

Space-web SPWB space-webs which, fill open space and are usually attached with mooring threads to different substrates. 
records of spiders previously recorded from the Kruger National Park.

\section{Guilds}

A guild is a group of species that potentially compete for jointly exploited limited resources (Polis \& McCormick 1986). Because most spiders live in a defined environment with limitations set by both physical conditions and biological factors (Foelix 1982), species can be grouped into guilds based on available information on their habitat preferences and predatory methods. For the present study two main guilds were recognised, namely wandering spiders (W) and web builders (WB), with further subdivisions based on micro-habitat and general behaviour (Table 1).

\section{Results and discussion}

\section{Numbers present}

Forty families represented by 116 genera and 152 species are presently known from the KNP (Table 2). Of the 152 species listed 103 are new records for the KNP (Table $2 \& 3$ ). The orb-web spiders of the family Araneidae are the most diverse and represented by 23 species, followed by the crab spiders (Thomisidae) with 15, the lynx spiders (Oxyopidae) with 9 and the wolf spiders (Lycosidae) and jumping spiders (Salticidae) with 8 species each. Fifteen families are represented by a single species. A total of 91 species are free living wandering spiders $(59 \%)$ while 61 species $(41 \%)$ build webs.

Table 2

Spider families collected at the Kruger National Park indicating the number of species and genera in each family and the number of species that are new records (NR)

\begin{tabular}{lccclccc}
\hline Family & Genera & Species & $\mathrm{Nr}$ & Family & Genera & Species & $\mathrm{Nr}$ \\
\hline Araneidae & 15 & 23 & 15 & Oxyopidae & 3 & 9 & 4 \\
Archaeidae & 1 & 1 & 0 & Palpimanidae & 1 & 1 & 1 \\
Barychelidae & 1 & 1 & 1 & Philodromidae & 3 & 4 & 3 \\
Caponiidae & 1 & 1 & 1 & Pholcidae & 3 & 3 & 3 \\
Corinnidae & 2 & 2 & 2 & Phyxelididae & 1 & 1 & 0 \\
Ctenidae & 1 & 1 & 1 & Pisauridae & 5 & 5 & 3 \\
Cyrtaucheniidae & 1 & 1 & 1 & Prodidomidae & 1 & 2 & 2 \\
Deinopidae & 1 & 1 & 1 & Salticidae & 8 & 8 & 7 \\
Dictynidae & 2 & 2 & 1 & Scytodidae & 1 & 1 & 1 \\
Dipluridae & 1 & 1 & 0 & Segestriidae & 1 & 1 & 1 \\
Eresidae & 3 & 6 & 2 & Selenopidae & 2 & 6 & 1 \\
Gnaphosidae & 6 & 6 & 1 & Sicariidae & 2 & 2 & 2 \\
Hersiliidae & 1 & 2 & 0 & Sparassidae & 3 & 3 & 2 \\
Idiopidae & 1 & 1 & 1 & Tetragnathidae & 5 & 7 & 6 \\
Linyphiidae & 2 & 2 & 1 & Theraphosidae & 4 & 5 & 1 \\
Liocranidae & 1 & 1 & 1 & Therididae & 5 & 5 & 5 \\
Lycosidae & 8 & 8 & 8 & Thomisidae & 9 & 15 & 14 \\
Mimetidae & 1 & 1 & 1 & Uloboridae & 1 & 2 & 2 \\
Miturgidae & 2 & 4 & 2 & Zodariidae & 4 & 4 & 2 \\
Oecobiidae & 2 & 2 & 2 & & & & \\
Oonopidae & 1 & 1 & 1 & Tot: 40 & 116 & 152 & 103 \\
& & & & & & & \\
\hline
\end{tabular}




\section{Ground wandering spiders}

Twenty-five families represented by 58 species are associated with the ground layer, 10 species live in burrows made in the ground, 36 species are free living and 12 are web dwellers.

\section{Web-building spiders}

Twelve species construct their webs on or close to the soil surface. The following web types were found: funnel-webs of the Dipluridae (Allothele malawi Coyle, 1984); retreat-webs of the Eresidae (Dresserus colsoni Tucker, 1920), Hersiliidae (Tama sp.), Oecobiidae (2 spp.) and the Phyxelididae (Xevioso orthomeles Griswold, 1990); space-web of the Pholcidae (3 spp.) funnelweb of the lycosid (Hippasa australis Lawrence, 1927) and the gumfoot-webs of the theridiids (Latrodectus geometricus C.L. Koch, 1841 and Steatoda capensis Hann, 1990).

\section{Free living ground spiders}

Thirty-six species (62\%) are free-living wanderers represented by 15 families. The more diverse families are the wolf spiders (Lycosidae) with 8 species, the ground spiders (Gnaphosidae) and the flatties (Selenopidae) both with 6 species each.

\section{Burrow living spiders}

Eight of the burrow dwellers found in the park belong to the suborder Mygalomorphae. They are represented by: two trapdoor spider families, Cyrtaucheniidae (Ancylotrypa barbertoni (Hewitt, 1913)) and Idiopidae (Idiops castaneus Hewitt, 1913); five baboon spider species of the family Theraphosidae; and one lesser baboon spider of the family Barychelidae. Of the mygalomorphs, the International Union for the Conservation of Nature (IUCN) (De Wet \& Schoonbee 1991) finds that it is mainly the larger Theraphosidae that are considered commercially threathened. Four of the theraphosid species, added to Schedule VII of the Transvaal Provincial Nature Conservation Ordinance of 1983 as Protected Invertebrate Animals, are found in the park (Dippenaar-
Schoeman 2002a; Gallon 2002), viz., Ceratogyrus bechuanicus Purcell, 1902, Harpactira gigas Pocock, 1898, Augacephalus breyeri (Hewitt, 1919) and A. junodi (Simon, 1904).

\section{Plant wandering spiders}

Web-building spiders

From the field layer $52 \%$ of the species (50) collected build webs. The orb-web spiders were the most diverse and represented by three families namely the Araneidae (23 spp.), Tetragnathidae (7 spp.) and Uloboridae (2 spp.). Members of the genera Argiope, Afracantha and Gasteracantha of the Araneidae and Leucauge, Nephila, Nephilengys and Tetragnatha of the Tetragnathidae construct large orb-webs between plants and are seen in their webs during the day. The tropical tent-web spider Cyrtophora citricola (Forskål, 1775) makes horizontal adapted orb-webs in plants like aloes. Most of the other orb-web species are nocturnal, e.g., the bark spider Caerostris, and remove their webs early each morning. The retreat webs of the Dictynidae, Eresidae and Segestriidae are made on different parts of the plants. Two species of the genus Stegodyphus, S. dumicola Pocock, 1898 and $S$. mimosarum Pavesi, 1883 are communal nest spiders found in large nests attached to the trees. The other web spiders construct gumfoot-webs (Theridiidae) and sheet-webs (Pisauridae and Linyphiidae). The large funnel-webs made vertically next to trees with the retreat part usually concealed in the plants or in abandoned animal holes are made by the large pisaurid Euprosthenops australis Simon, 1898.

Free living plant spiders

Ten families from 44 species are found on plants, with members of four families associated with bark, eight with grass, and four with leaves. The long spinnered bark spider Hersilia sericea Pocock, 1898 is a permanent inhabitant on bark, while members of the Philodromidae, Salticidae and Thomisidae are found on bark as well as 
Table 3

Check list of the spiders of the Kruger National Park

Family/genus/species

Guild Record

1. Family Araneidae

Afracantha camerunensis (Thorell, 1899)

Araneus apricus (Karsch, 1884)

Argiope australis (Walckenaer, 1805)

A. flavipalpis (Lucas, 1858)

A. trifasciata (Forskål, 1775)

Caerostris sexcuspidata (Fabricius, 1793)

Cyclosa insulana (Costa, 1834)

Cyphalonotus larvatus (Simon, 1881)

Cyrtophora citricola (Forskål, 1775)

Gasteracantha milvoides Butler, 1873

G. sanguinolenta C.L. Koch, 1844

G. versicolor (Walckenaer,1842)

Hypsacantha crucimaculata (Dahl, 1914)

Isoxya stuhlmanni (Bösenberg \& Lenz,1895)

I. tabulata (Thorell, 1859)

Kilima decens (Blackwall, 1866)

Nemoscolus vigintipunctatus Simon, 1897

Neoscona blondeli (Simon, 1885)

N. moreli (Vinson, 1863)

N. rufipalpis (Lucas, 1858)

N. subfusca (C.L. Koch, 1837)

Poltys furcifer Simon, 1881

Singa albodorsata Kauri, 1950

$\begin{array}{ll}\text { OWB } & \text { Emerit } 1973 \\ \text { OWB } & \text { NR } \\ \text { OWB } & \text { Bjørn 1997 } \\ \text { OWB } & \text { Bjørn 1997 } \\ \text { OWB } & \text { NR } \\ \text { OWB } & \text { NR } \\ \text { OWB } & \text { NR } \\ \text { OWB } & \text { NR } \\ \text { OWB } & \text { NR } \\ \text { OWB } & \text { NR } \\ \text { OWB } & \text { NR } \\ \text { OWB } & \text { Emerit } 1973 ; \\ & \text { Benoit \& Emerit } 1975 \\ \text { OWB } & \text { NR } \\ \text { OWB } & \text { NR } \\ \text { OWB } & \text { NR } \\ \text { OWB } & \text { NR } \\ \text { OWB } & \text { NR } \\ \text { OWB } & \text { Grasshoff } 1986 \\ \text { OWB } & \text { Grasshoff } 1986 \\ \text { OWB } & \text { NR } \\ \text { OWB } & \text { NR } \\ \text { OWB } & \text { NR } \\ \text { OWB } & \text { Kauri } 1950\end{array}$

2. Family Archaeidae

Afrarchaea bergae Lotz, 1996

FGW Lotz 1996a

3. Family Barychelidae

Brachionopus pretoriae Purcell, 1904

BGW NR

4. Family Caponiidae

Caponia natalensis (O.P.-Cambridge, 1874)

FGW NR

5. Family Corinnidae

Castianeira sp.

Merenius alberti Lessert, 1923

FGW NR

FGW NR

6. Family Ctenidae

Ctenus transvaalensis Benoit, 1981

FGW NR

7. Family Cyrtaucheniidae

Ancylotrypa barbertoni (Hewitt, 1913)

BGW NR

8. Family Deinopidae

Menneus camelus Pocock, 1902 O

WB NR

9. Family Dictynidae

Mashimo leleupi Lehtinen, 1967

RWB NR

Archaeodictyna ulova Griswold \& M-Griswold, 1987

RWB Griswold \& M-Griswold 1987

10. Family Dipluridae

Allothele malawi Coyle, 1984

FWB Coyle 1984

11. Family Eresidae

Dresserus colsoni Tucker, 1920

RWB NR 
Gandanameno purcelli Tucker, 1920

Stegodyphus africanus (Blackwall, 1866)

S. dumicola Pocock, 1898

S. mimosarum Pavesi, 1883

S. sabulosus Tullgren, 1910

12. Family Gnaphosidae

Aphantaulax inornata Tucker, 1923

Asemesthes purcelli Tucker, 1923

Camillina maun Platnick \& Murphy, 1987

Megamyrmaekion transvaalense Tucker, 1923

Scotophaeus marleyi Tucker, 1923

Zelotes tuckeri Roewer, 1951

13. Family Hersiliidae

Hersilia sericea Pocock, 1898

Hersilida sp. (immature)

14. Family Idiopidae

Idiops castaneus Hewitt, 1913

15. Family Linyphiidae

Tybaertiella krugeri (Simon 1894)

Meioneta habra Locket, 1968

16. Family Liocranidae

Rhaeboctesis trinotatus Tucker, 1920

17. Family Lycosidae

Arctosa transvaalana Roewer, 1960

Evippomma squamulatum (Simon, 1898)

Hippasa australis Lawrence, 1927

Hogna transvaalica (Simon, 1898)

Lycosa sp.

Pardosa crassipalpis Purcell, 1903

Pirata sp.

Proevippa albiventris (Simon, 1898)

18. Family Mimetidae

Mimetus natalensis Lawrence, 1938

19. Family Miturgidae

Cheiracanthium africanum Lessert, 1921

C. furculatum Karsch, 1879

Cheiramiona paradisus Lotz, 2002

C. krugerensis Lotz, 2002

20. Family Oecobiidae.

Oecobius navus Blackwall, 1859

Uroecobius sp. (immature)

21. Family Oonopidae

Opopaea speciosa (Lawrence, 1952).

22. FamilyOxyopidae

Hamataliwa kulczynskii (Lessert, 1915)

Oxyopes jacksoni Lessert, 1915

O. longispinosus Lawrence, 1938

O. pallidecoloratus Strand, 1906

Peucetia pulchra(Blackwall, 1865)

P. madalenae Van Niekerk \& Dippenaar-Schoeman, 1994 FPW

P. striata Karsch, 1878
RWB NR

RWB Kraus \& Kraus 1988

RWB Kraus \& Kraus 1988

RWB Kraus \& Kraus 1988

RWB Kraus \& Kraus 1988

FGW Tucker 1923

FGW Tucker 1923

FGW Platnick \& Murphy 1987

FGW Tucker 1923

FGW Tucker 1923

FGW NR

FPW Benoit 1967

RWB NR

BGW NR

SHWB Simon 1894

SHWB NR

FGW NR

$\begin{array}{ll}\text { FGW } & \text { NR } \\ \text { FGW } & \text { NR } \\ \text { FWB } & \text { NR } \\ \text { FGW } & \text { NR } \\ \text { BGW } & \text { NR } \\ \text { FGW } & \text { NR } \\ \text { FGW } & \text { NR } \\ \text { FGW } & \text { NR }\end{array}$

FPW NR

FPW Lotz 1996b*

FPW Lotz 1996b*

FPW Lotz 2002

FPW Lotz 2002

RWB NR

RWB NR

FGW NR

FPW NR

FPW NR

FPW NR

FPW NR

FPW Van Niekerk \& Dippenaar-

Schoeman 1994

Van Niekerk \& Dippenaar-

Schoeman 1994

Van Niekerk \& Dippenaar- 
P. transvaalica Simon, 1896

P. viridis (Blackwall, 1858)

23.Family Palpimanidae

Palpimanus transvaalicus Simon, 1893

24. Family Philodromidae

Philodromus rufus Walckenaer, 1825

Thanatus atlanticus Berland, 1936

T. vulgaris Simon, 1870

Tibellus sunetae Van den Berg \&Dippenaar- Schoeman 1994

25. Family Pholcidae

Leptopholcus sp. (immature)

Pholcus leptopholcicus Strand, 1909

Smeringopus natalensis Lawrence, 1947

26. Family Phyxelididae

Xevioso orthomeles Griswold, 1990

27. Family Pisauridae

Cispius problematicus Blandin, 1978

Euprosthenops australis Simon, 1898

Perenethis symmetrica (Lawrence, 1927)

Rothus purpurissatus Simon, 1898

Thalassius rossi Pocock, 1902

28. Family Prodidomidae

Theuma foveolata Tucker, 1923

T. fusca Purcell, 1907

29. Family Salticidae

Baryphas ahenus Simon, 1902

Brancus bevisi Lessert, 1925

Heliophanus transvaalicus Simon, 1901

Hyllus brevitarsis Simon, 1902

Myrmarachne laurentina Bacelar, 1953

Phlegra albostriata Simon, 1901

Portia schultzi Karsch, 1878

Thyene coccineovittata (Simon, 1885)

30. Family Scytodidae

Scytodes fusca Walckenaer, 1837

31. Family Segestriidae

Ariadna sp. (immature)

32.Family Selenopidae

Anyphops rubicundus (Lawrence, 1940)

A. silvicolellus (Strand, 1913)

Selenops krugeri Lawrence, 1940

S. ovambicus Lawrence, 1940

S. radiatus Latreille, 1819

S. tenebrosus Lawrence, 1940

33. Family Sicariidae

Loxosceles spiniceps Lawrence, 1952*

Sicarius oweni Newlands, 1986 *
FPW

Schoeman 1994

Van Niekerk \& Dippenaar-

Schoeman 1994

FPW Van Niekerk \& Dippenaar-

Schoeman 1994

FGW NR

FPW NR

FPW NR

FPW NR

FPW Van den Berg \& Dippenaar-

Schoeman, 1994

$\begin{array}{ll}\text { SPWB } & \text { NR } \\ \text { SPWB } & \text { NR } \\ \text { SPWB } & \text { NR }\end{array}$

RWB Griswold 1990

FPW Sierwald 1997

FWB NR

FPW Sierwald 1997

SHWB NR

FGW NR

FGW NR

FGW NR

FPW NR

FPW NR

FPW NR

FPW NR

FPW NR

FGW NR

FPW Wanless 1978

FPW NR

FGW NR

RWB NR

FGW Lawrence 1940

FGW Corronca 1998

FGW Corronca 2000

FGW Corronca 2000

FGW Corronca 2000

FGW NR

FGW NR

FGW NR 
34. Family Sparassidae

Olios correvoni Lessert, 1921

Palystes superciliosus L. Koch, 1875

FPW NR

Pseudomicrommata longipes Bösenberg \& Lenz, 1895

FPW

FPW

Croeser 1996

35. Family Tetragnathidae

Diphya simoni Kauri, 1950

Leucauge decorata (Blackwall, 1864)

Nephila pilipes (Fabricius, 1793)

$N$. senegalensis annulata (Thorell, 1859)

Nephilengys cruentata (Fabricius, 1775)

Tetragnatha boydi O.P.-Cambridge, 1898

T. subsquamata Okuma, 1985

$\begin{array}{ll}\text { OWB } & \text { Kauri } 1950 \\ \text { OWB } & \text { NR } \\ \text { OWB } & \text { NR } \\ \text { OWB } & \text { NR } \\ \text { OWB } & \text { NR } \\ \text { OWB } & \text { NR } \\ \text { OWB } & \text { Okuma \& Dippenaar-Schoeman } \\ & 1988\end{array}$

36. Family Theraphosidae

Augacephalus breyeri (Hewitt, 1919)

A. junodi (Simon, 1904)

BGW Gallon 2002

Ceratogyrus bechuanicus Purcell, 1902

BGW Gallon 2002

Harpactira gigas Pocock, 1898

BGW Smith 1990

Idiothele nigrofulva (Pocock, 1898)

BGW NR

BGW Gallon 2002

37. Family Theridiidae

Argyrodes convivans (Lawrence, 1937)

Latrodectus geometricus C.L. Koch, 1841

GWB NR

GWB NR

Phoroncidia eburnea (Simon,1895)

Steatoda capensis Hann, 1990

Theridion purcelli O.P.-Cambridge, 1940

GWB NR

GWB NR

GWB NR

38. Family Thomisidae

Misumenops rubrodecoratus Millot, 1942

Monaeses pustulosus Pavesi, 1895

M. quadrituberculatus Lawrence, 1927

Pactactes compactus Lawrence, 1947

FPW NR

FPW Dippenaar-Schoeman 1984

FPW NR

FPW NR

Runcinia aethiops (Simon, 1901)

FPW NR

R. flavida (Simon, 1881)

FPW NR

R. johnstoni Lessert, 1919

FPW

Simorcus cotti Lessert, 1936

Thomisops pupa Karsch, 1879

Thomisus daradioides Simon, 1890

T. granulatus Karsch, 1880

T. kalaharinus Lawrence, 1936

T. spiculosus Pocock, 1901

FPW NR

FPW NR

FPW NR

FPW NR

FPW NR

FPW NR

$\begin{array}{lll}\text { Tmarus africanus Lessert, } 1919 & \text { FPW } & \text { NR }\end{array}$

Xysticus sp.

FPW NR

39. Family Uloboridae

Uloborus planipedius Simon, 1896

OWB NR

U. plumipes Lucas, 1846

OWB NR

40. Family Zodariidae

Capheris transvaalica Hewitt, 1915 BGW NR

Chariobas sp.

Diores rectus Jocqué, 1990

Hermippus tenebrosus Jocqué, 1986

FPW NR

FGW Jocqué 1990

FGW Jocqué 1986

* from unpublished MSc and $\mathrm{PhD}$ theses.

$\mathrm{BGW}=$ burrow ground dwellers; FWB = funnel web; FGW = free living ground wanderer; FPW = free living plant wanderers; GWB $=$ gumfoot-web; $\mathrm{OWB}=$ orb-web; $\mathrm{NR}=$ new collecting record; $\mathrm{SHWB}=$ sheetweb; SPWB = space web. 
other parts of the plant. The KNP, as part of the Savanna Biome, is represented by about 32 grass-living species. Many of the grass dwellers are well camouflaged with elongated bodies, e.g., Runcinia spp. (Thomisidae), Tibellus sunetae Van den Berg \& DippenaarSchoeman, 1994 (Philodromidae) and Pseudomicrommata longipes Bösenberg \& Lenz, 1895 (Sparassidae), while others with their green or straw-coloured bodies blend in with the grass, e.g., members of the families Oxyopidae and Thomisidae.

\section{Conclusion}

Preliminary investigations into the biodiversity of invertebrate fauna in South Africa have highlighted the lack of baseline information on the ecology and diversity of most arachnid groups (Dippenaar-Schoeman $2002 b$ ). This survey of the KNP forms part of the South African National Survey of Arachnida (SANSA) and data gathered will be used in the Savanna Biome Project, Mpumalanga Biobase Programme and Arachnida in Conserved Area Projects.

Of the 2000 spiders presently known from South Africa (Dippenaar-Schoeman 2002b), the 152 species of KNP represent about $7.6 \%$ of the total spider fauna, with 103 species being new distribution records. Although this paper reports on sporadic collecting and probably represents only a portion of the spider fauna present, we hope this information will stimulate further research on this group of animals in the KNP. Future projects for the park include a key to the spiders and maps showing their distribution patterns.

\section{Acknowledgements}

We wish to thank the warden and officials of the Kruger National Park for their friendliness and assistance. Thanks are due to Dr. M.K.P. Smith Meyer and Ms. A. van den Berg, both of the ARC-Plant Protection Research Institute for reading the manuscript and Marie de Jager for additional spiders collected.

\section{References}

BENOIT, P.L.G. 1967. Révision des espèces africaines du genre Hersilia Sav. Et Aud. (Aran.-Hersiliidae). Revue de zoologie et de botanique africaines 76: 1-36.

Benoit, P.L.G. \& M. EMERIT. 1975. Mise à jour des connaissances concernant les Araneidae-Gasteracanthinae africains. Revue de Zoologie africaine 89: 321-336.

BJøRN, P. P. 1997. A taxonomic revision of the African part of the orb-weaving genus Argiope (Araneae: Araneidae). Entomologica Scandinavica 28: 199-239.

CorroncA, J. A.1998. uevos registros de Anyphops Benoit (Araneae, Selenopidae) y comentarios sobre su distribución. Biogeographica 74: 177 182.

CorroncA, J. A. 2000. Distribucion y nuevos registros de Selenops Latreille (Araneae, Selenopidae) en la región Afrotropical. Biogeographica 76: 89-94.

Coyle, E.A. 1984. A revision of the African mygalomorph spider genus Allothele (Araneae, Dipluridae). American Museum Novitates 2794: 1-20.

Croeser, P.M.C. 1996. A revision of the African huntsman spider genus Palystes L. Koch, 1875 (Araneae: Heteropodidae). Annals of the Natal Museum 37: 1-122.

De Wet, J.I. \& H.J. SchoonbeE. 1991. The occurrence and conservation status of Ceratogyrus bechuanicus and $C$. brachycephalus in the Transvaal, South Africa. Koedoe 34: 69-75.

DipPENAAR-SCHOEMAN, A.S. 1984. The crab-spiders of southern Africa (Araneae: Thomisidae). 4. The genus Monaeses Thorell, 1869. Phytophylactica 16: 101-116.

DippenaAR-Schoeman, A.S. 1988. Annotated check list of the spiders (Araneae) of the Mountain Zebra National Park. Koedoe 31: 151-160.

DippenAAR-Schoeman, A. S. 2002a. Baboon and trapdoor spiders of Southern Africa: an identification manual. Pretoria: Agricultural Research Council. (Plant Protection Research Institute Handbook 13)

DippenaAR-Schoeman, A.S. 2002b. Status of South African Arachnida fauna. Pp: 70-81. In: Status of South African species. Proceedings of symposium organized by the Endangered Wildlife Trust (EWT) of South Africa.

DippenaAr-Schoeman, A.S. \& C. Craemer. 2000. The South African National Survey of Arachnida (SANSA). Plant Protection News 56: 11-12

DippenaAr-Schoeman, A.S., A. Leroy, M. DE JAGER \& A. VAN DEN BERG. 1999. A checklist of the spider fauna of the Karoo National Park, South Africa (Arachnida: Araneae). Koedoe 42: 31-42. 
DippenaAr-Schoeman, A.S., A.M. Van Den Berg \& A. VAn Den Berg. 1989. Species composition and relative seasonal abundance of spiders from the field and tree layer of the Roodeplaat Dam Nature Reserve. Phytophylactica 22: 443-447.

EMERIT, M. 1973. Contribution à la connaissance des Araneidae Gasteracanthinae du sud-est africain: les Gastéracanthes du Natal Museum. Annals of the Natal Museum 21: 675-695.

FoELIX, R.F. 1982. Biology of spiders. Harvard University Press, Cambridge, Massachusetts.

FoORd, S.H., A.S. DippPENAAR-SChoEMAn \& M. VAN Der Merwe. 2002. A check list of the spider fauna of the Western Soutpansberg, South Africa (Arachnida: Araneae). Koedoe 45: 35-43

GALLON, R.C. 2002. Revision of the African genera Pterinochilus and Eucratoscelus (Araneae, Theraphosidae, Harpactirinae) with description of two new genera. Bulletin of the British Arachnological Society 12: 201-232.

GrasshofF, M. 1986. Die Radnetzspinnen-Gattung Neoscona in Afrika (Arachnida: Araneae). Annales du Musée royal de l'Afrique Centrale 250: 1-123.

GRISWOLD, C.E. 1990. A revision and phylogenetic analysis of the spider subfamily Phyxelidinae (Araneae, Amaurobiidae). Bulletin of the American Museum of Natural History 196: 1- 206.

Griswold, C.E. \& T.C. Meikle-Griswold. 1987. Archaeodictyna ulova, new species (Araneae: Dictynidae), a remarkable kleptoparasite of group-living eresid spiders (Stegodyphus spp., Araneidae: Eresidae). American Museum Novitates 2897: 1- 11.

JOCQUÉ, R. 1986. A revision of the genus Hermippus (Araneae, Zodariidae). Journal of Natural History 20: 7-22.

JOCQUÉ, R. 1990. A revision of the Afrotropical genus Diores (Araneae, Zodariidae). Annales $d u$ Museé royal de l'Afrique Centrale 260: 1-81.

KAURI, H. 1950. On some South African spiders and harvest spiders. Kunglige fysiografiska sällskapets 1 Lund Förhandlingar 20: 64-79.

Kraus, O. \& M. Kraus. 1988. The genus Stegodyphus (Arachnida, Araneae). Sibling species, species groups, and parallel origin of social living. Verhandlungen der Naturwissenschaftlichen Verein in Hamburg 30: 151-254.

LaWrence, R.F. 1940. The genus Selenops (Araneae) in South Africa. Annals of the South African Museum 32: 555-608.

Lotz, L.N. 1996a. Afrotropical Archaeidae (Araneae): 1. New species of Afrachaea with notes on Afrachaea godfreyi (Hewitt, 1919). Navorsinge van die Nasionale Museum, Bloemfontein 12: 141-160.
Lotz, L.N. 1996b. The genus Cheiracanthium (Araneae: Clubionidae) in southern Africa. MSc thesis, University of the Orange Free State, Bloemfontein.

LOTZ, L.N. 2002. A revision of the afrotropical genus Cheiramiona (Araneae: Miturgidae: Eutichurinae). Annales du Museé royal de l'Afrique Centrale 290: 39-86.

Okuma, C. \& A.S. DippenaAR-Schoeman. 1988. Tetragnatha (Araneae: Tetragnathidae) in the collection of the Plant Protection Research Institute, Pretoria with description of a new species. Phytophylactica 20: 219-232.

Polis, G.A. \& S.J. McCoRMICK. 1986. Scorpions, spiders and solpugids: predation and competition among distantly related taxa. Oecologia 71 : 111-116.

Platnick, N.I. \& J.A. MuRPHY. 1987. Studies on the Malagasy spiders. 3. The zelotine Gnaphosidae (Araneae, Gnaphosoidea) with a review of the genus Camillina. American Museum Novitates 2874: 1-33.

SIERWALD, P. 1997. Phylogenetic analysis of Pisaurine nursery web spiders, with revisions of Tetragonophthalma and Perenethis (Araneae, Lycosoidea, Pisauridae). The Journal of Arachnology 25: 361-407.

Simon, E. 1894. Histoire naturelle des Araignées 1(3), Paris 1894: 489-760.

Smith, A.M. 1990. A revision of the Theraphosidae family from Africa and the Middle East. UK: Fitzgerald Publishing.

TUCKER, R.W.E. 1923. The Drassidae of South Africa. Annals of the South African Museum 19: 251-438.

Van Den Berg, A. \& A.S. Dippenaar-Schoeman. 1994. A revision of the Afrotropical species of the genus Tibellus Simon (Araneae: Philodromidae). Koedoe 37: 67-114.

VAn Niekerk, P. \& A.S. DippenaAR-Schoeman. 1994. A revision of the Afrotropical species of Peucetia (Araneae: Oxyopidae). Entomology Memoir, Department of Agriculture, South Africa 89: 1-50.

WANLESS, E.R. 1978. A revision of the spider genus Portia (Araneae, Salticidae). Bulletin of the British Museum (Natural History), Zoology 34: 83-124.

Whitmore, C., R. Slotow, T.E. Crouch \& A.S. DipPENAAR-SCHOEMAN. 2001. Checklist of spiders (Araneae) from savanna ecosystem, Northern Province, South Africa: including a new family record. Durban Museum Novitates 26: 10-19. 